\title{
The Situation of Hepatosplenic Schistosomiasis in Brazil Today
}

\author{
Zilton A Andrade
}

Laboratório de Patologia Experimental, Centro de Pesquisas Gonçalo Moniz-Fiocruz, Rua Valdemar Falcão 121, 40295-001 Salvador, BA, Brasil

Specific chemotherapy against schistosomiasis together with environmental changes occurring in endemic areas of Brazil are causing a revolution in the clinico-pathological presentation of the disease when comparing to date from 10 to 15 years ago. To update the subject, an inquire was made among the most experienced Brazilian investigators in this field. They agree that a decrease of about 50 to $70 \%$ in prevalence, and an even higher decrease in incidence are taking place in Brazil today.

The prevalence of schistosome-infection has decreased in some areas and increased in other, with spreading sometimes occurring to peri-urban regions, indicating that schistosomiasis control depends on the application of multiple measures. General clinical and pathological manifestations related to hepatosplenic disease, such as ascites, gastric hemorrhages, big-spleen syndrome, cor pulmonale, glomerulopathy, etc. are also less severe nowadays than they used to be in the past.

Key words: schistosomiasis - hepatosplenic form - chemotherapy - environmental changes

From 1968 through 1977 three excellent curative drugs against schistosomiasis became available: hycanthone (1968), oxamniquine (1973) and praziquantel (1977). These new drugs, especially the last two, which can be administered orally in one single dose, presenting almost no contraindications, induced a great changes in the clinical pathological presentation of schistosomiasis, although not so much on its incidence and prevalence. The great breakthrough was the demonstration that treatment with the new drugs could be both curative and preventive of the most severe forms of the disease.

Bina (1984) observed that six years after the treatment of 115 patients in an endemic area of the State of Bahia, hepatosplenic disease disappeared in 4 out of 11 patients and none of the others with milder forms of the disease had their clinical condition aggravated, in spite of that, reinfection occurred in all of them. At the same time, from 115 non-treated controls, 21 developped hepatosplenic disease and 15 , previously presenting the hepatosplenic form of the disease, either remained as such or deteriorated further. These

Supported by Pronex.

Fax: +55-71-356.4292.

E-mail: zilton@server01.cpqgm.fiocruz.br

Received 4 May 1998

Accepted 31 August 1998 interesting results led Andrade and Bina (1985) to analyze necropsy protocols from the University Hospital at Salvador, Bahia. They observed that during 20 years (1956-1975) the percentage of necropsies performed on cases of hepatosplenic schistosomiasis maintained a constant level, between 6-7\% annually. From 1976 up to 1980 that percentage progressively decreased, reaching $1 \%$ by 1980 . Also, the predominance of young people noticed during the first 20-year period was reversed during the last period (1976-1980). Although these data could not be solely attributed to the advent of a new therapy, they did indicate that some important trends were lately occurring in the pathology of schistosomiasis. Another interesting report on the same subject was presented by Menezes Netto (1987). He observed that the population of the State of Sergipe increased 35\% in 13 years (1970-1983), while there was a $300 \%$ increase in surgical interventions (from $3.5 \%$ to $13.35 / 100,000$ inhabitants). However, splenectomy, a surgical treatment of choice for portal hypertension due to schistosomiasis, which represented $2.5 \%$ of all surgery during 1970 , diminished to $0.18 \%$ in 1983 (from 0.14 to $0.02 / 100,000$ inhabitants). It was estimated that cases of advanced schistosomiasis in Sergipe during 1983 represented only $1 / 5$ of those seen in 1970 .

Following these reports, several authors registered the regression of hepatosplenic schistosomiasis months or years later after curative treatment (Table I).

The existence of a curative drug, which was simple to administer and effective, stimulated 
TABLE I

Post-chemotherapy involution of hepatic fibrosis in schistosomiasis

\begin{tabular}{lllcll}
\hline Author & Year & Drug & $\begin{array}{l}\text { No. patients } \\
\text { treated }\end{array}$ & $\begin{array}{l}\% \text { of } \\
\text { involution }\end{array}$ & $\begin{array}{l}\text { Time after } \\
\text { treatment }\end{array}$ \\
\hline Bina \& Prata & 1983 & Hycanthone & $23^{a}$ & 20.0 & 6 years \\
Coutinho et al. & 1984 & Praziquantel & $46^{a}$ & 18.5 & 1 year \\
Dietze \& Prata & 1986 & Oxamniquine & $70^{a}$ & 40.0 & $6,18,24$ mos \\
Mohamed-Ali et al. & 1991 & Praziquantel & 420 & 20.0 & 6 mos \\
Dohering et al. & 1992 & Praziquantel & 322 & 14.9 & 23 mos \\
\hline
\end{tabular}

$a$ : hepatosplenic cases only.

official programs of large scale treatment of populations in endemic areas of Brazil (Coura 1995). In addition, since these new drugs became available throughout the country, many people are being treated in private offices and hospitals. One can then assume that a large scale treatment program of schistosomiais, official or not, has been taking place in Brazil for the last 10 to 15 years. Most results have not been published, but constitute the experience of several people who are working on schistosomiasis control in different parts of Brazil. However, hard data on record are only few. Clinicians, surgeons, epidemiologists and other medical personnel working in public hospitals all over Brazil concurs nowadays with the assumption that hepatosplenic schistosomiasis is gradually disappearing, in spite of the fact that schistosome-infection and transmission seem to have been much less affected. That is why the we should ask: "What is the situation of the advanced forms of schistosomiasis in Brazil today?"

\section{MATERIALS AND METHODS}

One should be aware of the fact that to report the real situation of severe schistosomiasis in Brazil today on consulting the current literature on the subject is not enough. Much of the existing data have probably not been published yet. The strategy used to collect data was to write letters to the most experienced professionals working in different endemic areas of schistosomiais in Brazil.

As expected, all of them promptly provided new data and were kind enough in authorizing the author to present them here. Therefore, all the credits belong to them. Their names will appear below. As for the errors or mistakes during interpretation of the data and the assumptions made in discussing them, I am solely responsible.

The inquiring-letter was very simple. It contained the following questions: (a) in your personal experience what is the present situation of the severe forms of schistosomiasis today? (b) how you compare the situation now with that before 1970 , 1980 ?, and (c) would you like to add any particular comment on the subject?

\section{RESULTS}

The main information obtained from the inquiring-letter were the followings:

Aluizio Prata (Faculty of Medicine, Uberaba, MG) considers that hepatosplenic schistosomiasis had a $70 \%$ reduction between the years of 1970 1990 in endemic zones of the State of Bahia, and that the same was true for cardio-pulmonary schistosomiasis. As an example, he gives the figures for one of the areas (Table II).

\section{TABLE II}

Advanced schistosomiasis in Brejo do Espírito Santo, State of Bahia

\begin{tabular}{lrrrr}
\hline Groups & 1977 & 1980 & 1985 & 1990 \\
\hline Hepatosplenic & 104 & 143 & 59 & 25 \\
Esplenectomized & 8 & 17 & 17 & 8 \\
Examined & 1,160 & 1,477 & 1,306 & 1,017 \\
\hline
\end{tabular}

(from A Prata)

From Recife, State of Pernambuco, Ana Lúcia Coutinho Domingues informed that from 1990 to $1996,1,184$ cases of hepatosplenic schistosomiasis were seen in one hospital service. Nowadays, all aspects of morbidity are less marked than they used to be some years ago. Episodes of gastric haemorrhages, presence of ascites, nephropathy and the cardio-pulmonary forms, which used to be about $10 \%$ in the $80 \mathrm{~s}$, range now in less than $1 \%$. The spleens are not as large as they appeared before, and the number of splenectomies decreased considerably. Although peri-urban schistosomiasis appears as a new public health problem, the mean age of the patients with hepatosplenic schistosomiasis in 1990 increased from 10 to 20 years in 1996, indicating the persistence of old cases.

José Rodrigues Coura (Instituto Oswaldo Cruz, Rio de Janeiro, RJ) observed that during the year 1997 patients with hepatosplenic schistosomiais in populations from endemic areas in the states of Minas Gerais, Sergipe and Paraíba comprised now less than $1 \%$. Table III presents his comparative data. 
From Vitória, State of Espírito Santo (Medical Institute, University of Espírito Santo) Fausto Edmundo Lima Pereira reported that in the 70s there were 2-3 necropsies per year made on people dying of hepatosplenic schistosomiasis, and none in the last two years. He consulted several surgeons and clinicians in his area and obtained the unanimous statement that hepatosplenic schistosomiasis was indeed decreasing its incidence and prevalence, although his consulted colleagues expressed different views on why these changes are occurring.

Naftale Katz (René Rachou Research CenterFiocruz, Belo Horizonte, MG) concluded that the decreasing in the number of cases of hepatosplenic schistosomiais nowadays is of about $50 \%$, but that, in his experience, it has always been associated with specific chemotherapy and/or other control measures, as confirmed when well controlled studies are performed.

All the colleagues consulted agreed that hepatosplenic schistosomiasis is showing a marked decrease in incidence and prevalence in Brazil today. The severe forms of the disease continue to be seen, but even then their manifestations are much less marked than they used to be. Schistosomal cor pulmonale is now a rarity according to all the colleagues consulted for this report. Interestingly schistosomal glomerulopathy continues to affect about $12 \%$ of hepatosplenic patients, the same as before (Correia et al. 1997). However, such glomerulopathy is now less frequently seen, since the overall number of hepatosplenic cases decreased, as seen in Table IV, taken from Correia et al. (1997).

\section{DISCUSSION}

There is now a consensus that hepatosplenic schistosomiasis is becoming rare in Brazil today. However, it is less clear why that is occurring. The impact from chemotherapy with oxamniquine and praziquantel is evident, but it is far from being the sole explanation. Before the advent of modern chemotherapy, there were already records showing that hepatosplenic schistosomiasis could
TABLE IV

Observations on schistosomal glomerulopathy in Salvador, State of Bahia, Brazil

\begin{tabular}{lccc}
\hline Period & No. necropsies & No. cases & $\%$ \\
\hline $1960 / 1970$ & 140 & 16 & 11.4 \\
$1980 / 1990$ & 34 & 4 & 12,9 \\
\hline
\end{tabular}

(from Correia et al. 1997)

expontaneously involute. In this regards, Katz and Brener (1966) made pioneering observations while studying patients in an endemic area within a 10year time-interval. Then, they observed that from 91 patients seen with the so-called hepato-intestinal schistosomiasis, 7 became hepatosplenic. As for the 21 cases already found with hepatosplenic disease, 6 deteriorated further, 7 remained stable, but 6 hepatosplenic patients involuted to the hepato-intestinal form. Only 3 of them presented a history of treatment. Considering the 30 patients with a history of treatment, they saw that 12 with mild schistosomiasis had their clinical condition aggravated in 5 and ameliorated in 7 , while among 8 hepatosplenic patients only 3 reversed this form. The AA considered that general environmental conditions remained unaltered in the area studied.

Severe schistosomiasis disappeared from some extensive endemic areas of the World (Japan, Venezuela, Puerto Rico) in the absence of any known special plan to erradicate it, but probably due to some important environmental changes.

During the period between 1950 and 1990 there was a general prevalence decrease in schistosomiasis in endemic areas of the State of Bahia, from $16.5 \%$ to $9.5 \%$. When analyzing prevalence data from 166 counties in that state, Carmo and Barreto (1994) observed a decrease in $68.7 \%$ of them, which was more marked in those areas showing a prevalence above $20 \%$ during the year 1950 . This situation sometimes correlated with mass chemotherapy, but, in other instances, rather with general environmental measures.

TABLE III

Cases of advanced schistosomiasis observed in some Brazilian localities and their time variation

\begin{tabular}{|c|c|c|c|c|}
\hline Localities & No. patients & $\%$ & Period & $\% \mathrm{HS} \mathrm{pts}^{a}$ \\
\hline Rio de Janeiro, RJ & 4,652 & & 1960-1979 & 12.81 \\
\hline Others & 4,870 & & & \\
\hline Capitão Andrade, MG & & $60.8 \%$ & 1973-1982 & 5.8 \\
\hline Padre Paraíso, MG & & $63.1 \%$ & $1973-1982$ & 4.4 \\
\hline Riachuelo, SE & & $50.5 \%$ & 1973-1982 & 2.4 \\
\hline Alhandra, PB & & $46.6 \%$ & 1973-1982 & 2.4 \\
\hline
\end{tabular}

$a$ : hepatosplenic patients (from JR Coura) 
Recently, Bina (1995) made an extensive field study in an endemic area of Bahia, controlling the transmission with molluscicides during 10 years and extending the observations to 5 years more after interruption of molluscicide application. His conclusions are important in stressing the importance of both chemotherapy and environmental modification on the prevalence of hepatosplenic schistosomiasis. He observed that parasite load positively correlates with clinico-pathological manifestations. The interruption of transmission by itself resulted in reduction of prevalence and morbidity up to a point of leading to reversion of hepatosplenic schistosomiasis. Specific chemotherapy increased the beneficial effects brought about by interruption of transmission.

Apparently constant re-infections seem to be essential for the development of severe schistosomiasis, since people who leave the endemic areas do not usually develop hepatosplenic disease while living in non-transmission areas (Coura et al. 1974). New measures, such as the installation of treated water, latrines, laundries and sanitary education are gradually improving in Brazil today, and all that contributes to diminish schistosomiasis transmission. Specific chemotherapy is another important factor.

Being a pathologist interested on the biology of extracellular matrix, the whole problem of schistosomiais appears to me as dependent on an important biological fact: the dynamic concept of fibrogenesis. Schistosomiais causes disease by causing fibrosis. Fibrosis represents the deposition of an excess of extracellular matrix. During this deposition, there are two forces in action: one that stimulates the synthesis of extracellular matrix by the inflammatory and connective tissue cells, and the other that operates in inhibiting those stimuli or by removing parasitic stimuli, which induces the matrix degradative forces to operate (Rojkind $\&$ Greenwel 1994). The schistosome eggs are potent fibrogenic factors. If their number decreases because the worms die either expontaneously (through the action of the host immune system?) or because they are killed by chemotherapy, the forces of fibrogenesis decrease and those of fibrolysis become prominent (Andrade 1994).

These new dynamic concepts that govern the biology of the extracellular matrix are in the roots of the changing pattern of the pathology of schistosomiasis that we are witnessing nowadays.

\section{REFERENCES}

Andrade ZA 1994. Extracellular matrix degradation in parasitic diseases. Braz J Med Biol Res 27: 22732281.

Andrade ZA, Bina JC 1985. The changing pattern of pathology due to Schistosoma mansoni infection.
Mem Inst Oswaldo Cruz 80: 363-366.

Bina JC 1977. Influência da Terapêutica Específica na Evolução da Esquistossomose, MSC Thesis, UFBA, Salvador, BA, 58 pp.

Bina JC 1995. Estudo de Variáveis que Podem Influenciar na Evolução da Esquistossomose Mansônica. Efeito da Terapêutica Específica e da Interrupção da Transmissão, $\mathrm{PhD}$ Thesis, UFBA, Salvador, BA, $126 \mathrm{pp}$.

Bina JC, Prata A 1983. Regressão da hepatoesplenomegalia pelo tratamento específico da esquistossomose. Rev Soc Bras Med Trop 16: 213-218.

Carmo EH, Barreto ML 1994. Esquistossomose mansônica no Estado da Bahia, Brasil: tendências históricas e medidas de controle. Cad Saúde Públ 10: 425-439.

Coura JR 1995. Control of schistosomiasis in Brazil. Perspectives and proposals. Mem Inst Oswaldo Cruz 90: 257-260.

Coura JR, Wanke B, Figueiredo N, Argento CA 1974. Evolutive pattern of schistosomiasis and life-span of Schistosoma mansoni in patients living in nonendemic area in Brazil. Rev Soc Bras Med Trop 8: 193-198.

Coutinho AD, Domingues ALC, Florencio JN, Almeida ST 1984. Tratamento da esquistossomose mansônica hepatoesplênica com praziquantel. Rev Inst Med Trop $S$ Paulo 26: 38-50.

Correia EIS, Martinellki RP, Rocha H 1997. Está desaparecendo a glomerulopatia da esquistossomose mansônica? Rev Soc Bras Med Trop 30: 341-343.

Dietze RS, Prata A 1986. Rate of reversion of hepatosplenic schistosomiasis after specific chemotherapy. Rev Soc Bras Med Trop 19: 69-73.

Doehring-Schwerdtfeger E, Abdel-Rahim IM, Kardorff R, Kaiser C, Franke D, Schlake J, Richter J, Elsheikh M, Mohamed-Ali Q, Ehrich JHH 1992. Ultrasonagraphic investigation of periportal fibrosis in children with Schistosoma mansoni infection: reversibility of morbidity twenty-three months after treatment with praziquantel. Am J Trop Med Hyg 46: 409-415.

Katz N, Brener Z 1966. Evolucão clínica de 112 casos de esquistossomose mansoni observados após dez anos de permanência em focos endêmicos de Minas Gerais. Rev Inst Med Trop S Paulo 8: 139-142.

Menezes Netto AG 1987. Esplenectomia e derivação espleno-renal distal realizadas em Sergipe antes e após o programa especial de controle da esquistossomose (PECE). Rev Soc Bras Med Trop 20: 41-43.

Mohamed-Ali Q, Doehring-Schwerdtfeger E, AbdelRahim IM, Schlake J, Kardoff R, Franke D, Kaiser C, Elsheikh M, Abdalla S, Schafer P, Ehrich JHH 1991. Ultrasonographic investigation of periportal fibrosis in children with Schistosoma mansoni infection: reversibility of morbidity seven months after treatment with praziquantel. Am J Trop Med Hyg 44: 444-451.

Rojkind M, Greenwel P 1994 The extracellular matrix of the liver, $\mathrm{p}$ 843-868. In IM Arias, JL Boyer, N Fausto, WB Jacoby, DA Schachter, DA Shafritz (eds), The Liver, Biology and Pathobiology, Raven Press, New York. 